\title{
ETNOFARMASI TUMBUHAN OBAT DI DESA PECORO KECAMATAN RAMBIPUJI KABUPATEN JEMBER
}

\author{
Neny Ismiyanti ${ }^{1 *}$, Alvita Maulida Diana ${ }^{1}$, Sayyidatur Rizqiyah $^{1}$, \\ Andika Moh. Syafiullah ${ }^{1}$
}

\author{
${ }^{1}$ Program Studi Tadris IImu Pengetahuan Alam, Universitas KH. Achmad Shiddiq Jember \\ *Corresponding Author:: nenyismiyanti@gmail.com
}

\section{DOI: 10.35719/vektor.v2i2.36}

\begin{abstract}
Abstrak. Keberagaman hayati yang tesimpan di alam Indonesia membawa manfaat salah satunya dalam hal kesehatan. Mayoritas masyarakat Indonesia masih mempertahankan tradisi mengobati penyakit dengan menggunakan tumbuhan obat. Untuk melestarikan pengetahuan masyarakat akan khasiat tumbuhan obat dipelajari dalam ilmu etnofarmasi. Penelitian ini bertujuan untuk menggali pengetahuan etnik lokal terhadap resep tradisional berkhasiat obat pada masyarakat Desa Pecoro Rambipuji Jember. Studi etnofarmasi tumbuhan obat di desa Pecoro Rambipuji Jember telah dilakukan dari bulan Mei-Juni 2021. Pada penelitian ini menggunakan dua tahap, tahap yang pertama yaitu melakukan proses penggalian potensi masyarakat di desa Pecoro sebagai tempat dilakukannya penelitian dengan menggunakan metode observasi partisipatif dan wawancara terbuka dan tahap yang kedua yaitu adalah pengumpulan data. Berdasarkan hasil penelitian diketahui bahwa masyarakat di desa Pecoro kecamatan Rambipuji tercatat menggunakan 17 spesies tumbuhan dari 12 famili. Dalam penggunaan tanaman obat tersebut, terdapat 7 macam khasiat di antaranya pengobatan setelah melahirkan, diabetes, diare, batuk, sariawan, rematik, dan asam urat.
\end{abstract}

Kata Kunci: Etnofarmasi; tumbuhan obat; pengobatan tradisional.

Abstract. Biodiversity stored in the nature of Indonesia brings benefits, one of which is in terms of health. Indonesian people still maintain the tradition of treating diseases using medicinal plants. Without public knowledge of the efficacy of medicinal plants studied in ethnopharmaceutical science. This study aims to explore local ethnic knowledge of traditional recipes with medicinal properties in the people of Pecoro Rambi Puji Jember Village. The ethnopharmaceutical study of medicinal plants in the village of Pecoro Rambi Puji Jember has been carried out from May-June 2021. In this study using two stages, the first stage is to process the potential of the community in Pecoro village as a research place using participatory observation methods and open interviews and the second stage is data collection. Results Based on the research, it is known that the people in Pecoro village, Rambi Puji sub-district were recorded using 17 plant species from 12 families. In the use of these medicinal plants, there are 7 kinds of properties including treatment after childbirth, diabetes, diarrhea, cough, thrush, rheumatism, and gout.

Keywords: Ethnopharmacy; medicinal plants; traditional medicine. 


\section{PENDAHULUAN}

Indonesia dikenal dengan sebutan negara kepulauan yang memiliki kekayaan akan keanekaragaman hayatinya, bahkan Indonesia mempunyai hutan tropika terbesar kedua di dunia yang dikenal pula sebagai negara megabiodiversity (Ersam, 2004). Dengan ribuan pulau yang membentang dari Sabang hingga Merauke dengan berbagai suku dan etnik yang menghuni, maka Indonesia dapat melahirkan banyak kearifan lokal sesuai dengan budaya dan adat istiadat yang dipegang teguh secara turun-menurun sebagai sebuah tradisi. Persepsi masyarakat mengenai kesembuhan suatu penyakit terbentuk melalui suatu proses sosialisasi yang secara turun-temurun dipercaya dan diyakini kebenarannya (Moelyono, 2014). Kepercayaan masyarakat mengenai penggunaan obat tradisional diyakini dapat menjadi alternatif untuk menyembuhkan penyakit. Bukti adanya penggunaan obat tradisional di Indonesia sudah dilakukan sejak berabad-abad yang lalu diantaranya dapat dilihat pada relief candi Prambanan dan candi Borobudur, tertulis dalam daun lontar, serta peninggalan budaya di keraton-keraton. Pengetahuan mengenai obat tradisional (jamu) dapat kita temui dalam naskah Serat Kawruh dan Serat Centhini. Dan penggunaan obat tradisional yang dilakukan masyarakat Sulawesi Tenggara dapat dilihat dalam naskah lontaraq pabbura (Depkes RI, 2007).

Pengetahuan masyarakat lokal akan penggunaan obat tradisional diwariskan dari nenek moyang yang dilakukan dengan cara oral atau dari mulut ke mulut. Masuknya budaya modern ditengah-tengah masyarakat tradisional dikhawatirkan dapat menyebabkan tradisi lokal lambat laun akan hilang. Hal ini harus didorong dengan upaya pelestarian pengetahuan lokal akan penggunaan obat tradisional sedini mungkin. Salah satu cara yang bisa dilakukan untuk mengedukasi generasi bangsa adalah dengan melakukan pendekatan etnofarmasi (Bodeker, 2000). Studi etnofarmasi ialah sebuah pendekatan ilmiah yang dapat membantu kita dalam menggali pengetahuan etnik lokal terhadap resep tradisional berkhasiat obat. Penelitian berbasis etnofarmasi sangat penting untuk memberikan pemahaman masyarakat modern akan suatu cara pengobatan tradisional yang dilakukan dan juga penelitian berbasis etnofarmasi ini dapat digunakan sebagai penelitian yang memaparkan perbandingan pengobatan modern dengan pengobatan dalam suatu suku (Syifa, 2011).

Penggunaan obat yang berasal dari tumbuhan merupakan suatu pendekatan yang sangat banyak dilakukan sebagai upayah merawat kesehatan tubuh (Heinrich dkk, 2009). Kurangnya minat generasi muda untuk menerapkan pengetahuan lokal dan tidak adanya pewarisan pengetahuan dari leluhur menyebabkan kearifan lokal lambat laun mengalami erosi (Suryana dan Iskandar, 2014). Berdasarkan beberapa permasalahan yang sudah disebutkan diatas, peneliti tertarik untuk mengkaji pengetahuan yang terdapat pada masyarakat lokal khususnya pada kajian etnofarmasi. Hal yang digali dalam penelitian ini adalah bagaimana pengetahuan masyarakat lokal terhadap penggunaaan berbagai jenis tumbuhan yang digunakan sebagai obat pada masyarakat desa Pecoro Kecamatan Rambipuji Kabupaten Jember. Tujuan penelitian ini adalah untuk menggali pengetahuan lokal tentang jenis-jenis tanaman obat yang digunakan dalam pola pengobatan tradisional pada masyarakat Desa Pecoro Rambipuji Jember. 


\section{METODE}

Jenis penelitian ini adalah deskriptif kualitatif. Penelitian tentang etnofarmasi dilaksanakan di desa Pecoro, Kecamatan Rambipuji, Kabupaten Jember, Jawa Timur. Penelitian ini dilaksanakan dengan 2 kali tahapan, Tahap pertama dilakukan dengan proses menggali potensi masyarakat di desa Pecoro sebagai tempat penelitian dengan cara observasi (mardawani 2020).

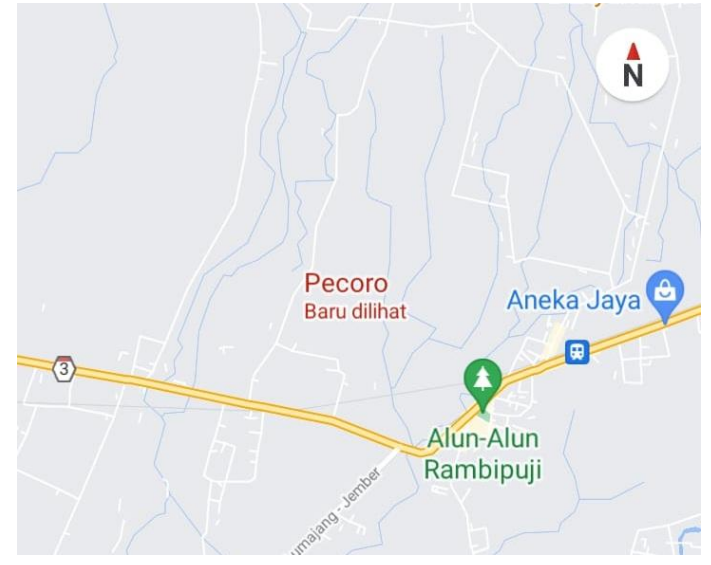

Gambar 1. Peta Lokasi Penelitian

Observasi dilakukan dengan cara mencari tahu tradisi masayarakat yang ada di desa Pecoro, Kecamatan Rambipuji, Kabupaten Jember yang berkaitan dengan pemanfaatan tumbuhan obat. Serta meminta rekomendasi masyarakat setempat mengenai sumber informan yang dianggap paling tahu dan sering menggunakan tanaman tradisional sebagai bahan obat.

Tahap kedua yaitu adalah pengumpulan data. Tahap pengumpulan data dilakukan dengan wawancara bebas terpimpin, yang artinya pertanyaan yang dilontarkan kepada narasumber tidak terpaku pada lembar pedoman wawancara dan pertanyaan bisa dikembangkan sesuai dengan situasi dan kondisi yang ada di lapangan. Data yang didapatkan dari informan berupa nama lokal tumbuhan, khasiat dan kegunaan, organ tumbuhan yang digunakan, dan cara penggunaannya (Idolo et al. 2009). Jumlah informan yang dipilih sebanyak 4 orang dengan kriteria menggunakan tumbuhan obat dalam kesehariannya. Data yang didapatkan kemudian dianalisis berdasarkan famili tumbuhan, nama lokal, organ tumbuhan yang digunakan serta tata cara penggunaannya sesuai penyakit yang ingin disembuhkan.

Teknik pengambilan sampel pada penelitian ini menggunakan purposive sampling dan snowball sampling, yang mana apabila informasi yang didapat kurang kami meminta rekomendasi narasumber untuk mencari sumber informan lain yang terpercaya. Metode pengumpulan data menggunakan metode wawancara terbuka. Analisis data yang digunakan menggunakan analisis studi literatur.

Teknik analisis data yang digunakan untuk mengetahui jenis tanaman obat yang banyak digunakan di desa tersebut dengan menggunakan Use Value. Semakin tinggi nilai UV yang diperoleh menunjukan jenis tanaman utama yang sering digunakan masyarakat (Syukrillah, dkk. 2021)menghitung nilai Use Value seperti berikut (Kurniawan and Jadid 2015) 


$$
\text { UVs }=\frac{\sum U V i s}{n i}
$$

\section{Keterangan :}

$U V_{\mathrm{s}}$ : Nilai guna spesies

$U V_{\text {is }}$ : Jumlah nilai yang diperoleh dari setiap spesies

$n_{i}$ : jumlah total responden yang di interview

\section{HASIL DAN PEMBAHASAN}

Berdasarkan hasil wawancara bersama beberapa sumber informan di desa Pecoro, Kecamatan Rambipuji kami mendapatkan 4 orang narasumber yang mengerti akan penggunaan tumbuhan yang berkhasiat obat. Tumbuhan jenis obat yang digunakan masyarakat desa Pecoro terdapat 16 spesies tumbuhan dari 12 famili. Adapun jenis tumbuhan yang digunakan masyarakat desa Pecoro, Kecamatan Rambipuji meliputi.

Tabel 1. Famili, Spesies, Organ tumbuhan, Kegunan

\begin{tabular}{|l|l|l|l|}
\hline Famili & $\begin{array}{l}\text { Nama spesies } \\
\text { /nama lokal }\end{array}$ & $\begin{array}{c}\text { Organ } \\
\text { tumbuhan } \\
\text { yang } \\
\text { digunakan }\end{array}$ & \multicolumn{1}{|c|}{ Kegunaan } \\
\hline Zingiberaceae & $\begin{array}{l}\text { Curcuma } \\
\text { longa } \\
\text { kunyit }\end{array}$ & Rimpang & $\begin{array}{l}\text { Menyehatkan } \\
\text { badan, radang } \\
\text { usus, luka } \\
\text { bernanah, Jamu } \\
\text { setelah } \\
\text { melahiran }\end{array}$ \\
\hline Piperaceae & $\begin{array}{l}\text { Piper betle / } \\
\text { sirih }\end{array}$ & Daun & $\begin{array}{l}\text { Mengobati } \\
\text { masuk angin, } \\
\text { mimisan, } \\
\text { mengobati } \\
\text { organ } \\
\text { kewanitaan, } \\
\text { memperkuat } \\
\text { gigi }\end{array}$ \\
\hline Rutaceae & $\begin{array}{l}\text { Citrus } \\
\text { aurantifolia/ } \\
\text { jeruk nipis }\end{array}$ & $\begin{array}{l}\text { Buah } \\
\text { indica/ }\end{array}$ & $\begin{array}{l}\text { Mengobati } \\
\text { sariawan }\end{array}$ \\
\hline Asteraceae & Daun & $\begin{array}{l}\text { Memperlancar } \\
\text { asi, }\end{array}$ \\
\hline
\end{tabular}




\begin{tabular}{|c|c|c|c|}
\hline & beluntas & & $\begin{array}{l}\text { setelah } \\
\text { melahiran }\end{array}$ \\
\hline Moraceae & $\begin{array}{l}\text { Arthocarpus } \\
\text { heterophyllus } \\
\text { / pohon } \\
\text { nangka }\end{array}$ & Buah & Mengobati diare \\
\hline Oxalidaceae & $\begin{array}{l}\text { Averrhoa } \\
\text { bilimbi / } \\
\text { belimbing } \\
\text { wuluh }\end{array}$ & Bunga & $\begin{array}{l}\text { Mengobati } \\
\text { batuk }\end{array}$ \\
\hline Zingiberaceae & $\begin{array}{l}\text { Alpinia } \\
\text { galaga / } \\
\text { lengkuas }\end{array}$ & Rimpang & $\begin{array}{l}\text { Mengobati } \\
\text { rematik, asam } \\
\text { urat }\end{array}$ \\
\hline Arecaceae & $\begin{array}{l}\text { Salacca } \\
\text { zalacca } \\
\text { salak }\end{array}$ & Buah & Diare \\
\hline Poaeceae & 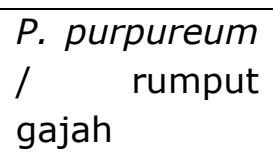 & Batang & Diabetes \\
\hline Phyllanthaceae & $\begin{array}{l}\text { Phyllanthus } \\
\text { urinaria / } \\
\text { meniran }\end{array}$ & Daun & $\begin{array}{l}\text { Jamu setelah } \\
\text { melahirkan }\end{array}$ \\
\hline Zingiberaceae & $\begin{array}{l}\text { Kempferia } \\
\text { galangal / } \\
\text { kencur }\end{array}$ & Rimpang & $\begin{array}{l}\text { Mengobati } \\
\text { masuk angin, } \\
\text { meningkatkan } \\
\text { nafsu makan, } \\
\text { menyegarkan } \\
\text { tubuh, } \\
\text { menyehatkan } \\
\text { otot }\end{array}$ \\
\hline Clusiaceae & $\begin{array}{l}\text { Garcinia } \\
\text { mangostana / } \\
\text { manggis }\end{array}$ & $\begin{array}{l}\text { Kulit } \\
\text { manggis }\end{array}$ & $\begin{array}{l}\text { Mengobati } \\
\text { diabetes, } \\
\text { Tekanan darah } \\
\text { tinggi }\end{array}$ \\
\hline Zingiberaceae & $\begin{array}{l}\text { Curcuma } \\
\text { xanthorrhiza } \\
\text { / temu lawak }\end{array}$ & Rimpang & $\begin{array}{l}\text { Mengobati } \\
\text { lambung, } \\
\text { Rematik, Sakit } \\
\text { pinggang }\end{array}$ \\
\hline
\end{tabular}




\begin{tabular}{|l|l|l|l|}
\hline Muntingiaceae & $\begin{array}{l}\text { M. calabura / } \\
\text { buah ceri / } \\
\text { kersen }\end{array}$ & Daun & Diabetes \\
\hline Poaceae & $\begin{array}{l}\text { C. citratus / } \\
\text { serai }\end{array}$ & $\begin{array}{l}\text { Daun } \\
\text { verum / Kayu } \\
\text { Manis }\end{array}$ & $\begin{array}{l}\text { Pohon } \\
\text { Kolesterol }\end{array}$ \\
\hline Lauraceae & $\begin{array}{l}\text { Zingiber } \\
\text { officinale / } \\
\text { Jahe }\end{array}$ & $\begin{array}{l}\text { Mengobati } \\
\text { kolesterol, gula } \\
\text { darah }\end{array}$ \\
\hline Zingiberaceangang & $\begin{array}{l}\text { Memperlancar } \\
\text { aliran darah, } \\
\text { manghangatkan } \\
\text { tubuh }\end{array}$ \\
\hline
\end{tabular}

Tabel 2. Persentase Jenis Tanaman Obat yang Digunakan Oleh Masyarakat Desa

\begin{tabular}{|c|c|c|c|c|c|c|}
\hline \multirow[t]{2}{*}{ No. } & \multirow{2}{*}{$\begin{array}{c}\text { Jenis } \\
\text { Tanaman }\end{array}$} & \multicolumn{4}{|c|}{ Responden } & \multirow[t]{2}{*}{ Persentase (\%) } \\
\hline & & 1 & 2 & 3 & 4 & \\
\hline 1. & Kunyit & $\checkmark$ & $\checkmark$ & $\checkmark$ & $\sqrt{ }$ & $1 \%$ \\
\hline 2. & Sirih & $\checkmark$ & $\checkmark$ & & $\sqrt{ }$ & $0,75 \%$ \\
\hline 3. & Jeruk nipis & $\checkmark$ & & & $\checkmark$ & $0,5 \%$ \\
\hline 4. & Beluntas & & $\checkmark$ & $\checkmark$ & & $0,5 \%$ \\
\hline 5. & Pohon Nangka & & & $\sqrt{ }$ & & $0,25 \%$ \\
\hline 6. & $\begin{array}{l}\text { Belimbing } \\
\text { Wuluh }\end{array}$ & & $\checkmark$ & $\sqrt{ }$ & & $0,5 \%$ \\
\hline 7. & Lengkuas & $\checkmark$ & $\checkmark$ & $\sqrt{ }$ & $\sqrt{ }$ & $1 \%$ \\
\hline 8. & Salak & & $\checkmark$ & & & $0,25 \%$ \\
\hline 9. & Rumput Gajah & & & $\checkmark$ & & $0,25 \%$ \\
\hline 10. & Meniran & & & & $\checkmark$ & $0,25 \%$ \\
\hline 11. & Kencur & & $\checkmark$ & $\checkmark$ & $\checkmark$ & $0,75 \%$ \\
\hline 12. & Manggis & $\sqrt{ }$ & & & $\sqrt{ }$ & $0,5 \%$ \\
\hline
\end{tabular}




\begin{tabular}{|c|c|c|c|c|c|c|}
\hline 13. & Temu Lawak & & & $\checkmark$ & $\checkmark$ & $0,5 \%$ \\
\hline 14. & Kersen & $\checkmark$ & & & & $0,25 \%$ \\
\hline 15. & Serai & $\checkmark$ & $\checkmark$ & & $\checkmark$ & $0,75 \%$ \\
\hline 16. & Kayu manis & $\checkmark$ & & $\checkmark$ & & $0,5 \%$ \\
\hline 17. & Jahe & $\checkmark$ & $\checkmark$ & $\checkmark$ & $\checkmark$ & $1 \%$ \\
\hline
\end{tabular}

Berdasarkan hasil wawancara pada 4 informan di desa Pecoro. Diketahui bahwa terdapat 17 spesies tumbuhan yang digunakan sebagai obat. Beberapa masyarakat desa Pecoro menggunakan tumbuhan sebagai obat tradisional mendapatkan pengetahuan ini secara turun temurun dari nenek moyang atau orang tua terdahulu. Berdasarkan informasi dari beberapa sumber terpercaya, bahwa masyarakat yang masih menggunakan obat tradisional memanfaatkan beberapa bagian dari tumbuhan tersebut seperti kulit, buah, rimpangnya,bunga, batang dan daun. Karto menjelaskan bahwa salah satu komponen lingkungan yang digunakan oleh manusia dalam memperoleh hidup yang sehat adalah dengan menggunakan tumbuhan, dalam bentuk jamu atau obat tradisional (Indah Yulia Ningsih. 2016).

Seperti yang sudah dilihat di Tabel 1. Bahwa terdapat berbagai macam tumbuhan yang digunakan oleh masyarakat desa Pecoro. Beberapa kandungan tumbuhan yang digunakan oleh masyarakat desa Pecoro antara lain yaitu, Kunyit, organ tumbuhan yang digunakan untuk mengobati penyakit disini adalah menggunkaan bagian rimpangnya. Penelitian telah menunjukkan bahwa kurkumin memiliki antioksidan kuat, penyembuhan luka, dan sifat anti-inflamasi (Fannia Kusuma,dkk.2017). Komponen utama dalam rimpang kunyit adalah kurkumin dan minyak atsiri. Kemudian temulawak, kandungan dalam temulawak berisi senyawa-senyawa kimia yang memiliki kandungan aktif secara fisiologi, yaitu kurkuminoid dan minyak atsiri. Kandungan kurkuminoid dalam temulawak berfungsi sebagai antibakteria, anti-kanker, anti-tumor, serta mengandung antioksidan. Kandungan kurkuminoid dalam temulawak berkisar $1-2 \%$ dan kandungan minyak atsiri dalam temulawak berkisar 3-12\% (Dermawaty. 2015). Lalu kulit buah manggis. Kulit buah manggis ini dianggap istimewa karena mengandung senyawa xanton. Hasil penelitian lainnya menunjukkan bahwa komponen seluruh buah manggis yang paling besar adalah kulitnya, yakni 70-75\%, sedangkan daging buahnya hanya $10-15 \%$ dan bijinya $15-20 \%$. Kandungan xanton tertinggi terdapat dalam kulit buah manggis, yakni 107,76 mg per $100 \mathrm{~g}$ kulit buah (Eddy Yatman.2012).

Hasil perhitungan pada Tabel 2. menujukan terdapat beberapa jenis tanaman utama yang banyak digunakan masyarakat desa Pecoro ialah tanaman Kunyit (Curcuma longa), lengkuas (Alpinia galaga), jahe (Zingiber officinale) dengan persentase sebesar $1 \%$, dan tanaman sirih (Piper bet/e), kencur (Kempferia galangal), serai (C. Citratus) dengan persentase sebesar $0,75 \%$. Jenis tanaman tersebut digunakan masyarakat desa Pecoro dalam mengobati penyakit diantaranya : rematik dan asam urat. 
Berdasarkan jenis penyakit yang diobati oleh masyarakat desa Pecoro ada beberapa macam cara yang dapat digunakan untuk mengelolah tumbuhan tersebut agar mendapatkan khasiatnya. Adapun cara pengelolaan tumbuhan yang dilakukan di desa Pecoro antara lain direbus, ditumbuk, diparut, atau dikonsumsi secara langsung dan cara penggunaan yang dilakukan bisa diminum, dimakan

Tumbuhan obat yang digunakan oleh masyarakat desa Pecoro di Kecamatan Rambipuji tidak hanya digunakan untuk satu atau dua macam penyakit saja, namun bisa digunakan untuk beberapa macam penyakit. Berdasarkan hasil wawancara bersama sumber informan, terdapat beberapa penyakit yang dapat diobati oleh tumbuhan yang ada disekitar. Beberapa penyakit yang dapat diobati dengan tumbuhan obat terdapat 7 macam penyakit.

Berikut ini cara pengelolahan tumbuhan obat oleh masyarakat desa Pecoro:

1. Pengobatan setelah melahirkan

Menurut informan apabila ada ibu yang baru saja melahirkan biasanya diberikan jamu olahan dari tumbuhan beluntas dan meniran yang sudah menjadi kebiasaan dan diyakini dapat meredakan sakit usai melahirkan. Cara pengelolahan tumbuhan tersebut yaitu :
a. Cuci terlebih dahulu bahan yang akan digunakan
b. Setelah bersih bahan tersebut di tumbuk dengan tekstur kasar
c. Kemudian rebus sampai mendidih
d. Dan diamkan sampai dingin
e. Lalu diminum sehari 3 kali

2. Diabetes

Menurut informan dan sumber literasi yang didapatkan bahwa kulit manggis dapat mengobati penyakit diabetes, tidak hanya itu saja masayarakat desa Pecoro juga menggunakan daun kersen dan rumput gajah sebagai pengobatan penyakit diabetes. Cara pengelolahannya yaitu:

a. Jemur kulit manggis sampai kering

b. Kemudian di rebus lalu diambil airnya

c. Dan diminum secukupnya

Cara mengolah daun kersen dan rumput gajah bagi penderita diabetes dan kolestrol :
a. Cuci bersih daun kersen yang akan digunakan
b. Kemudian rebus
c. Caranya juga sama seperti kulit manggis

3. Diare

Menurut informan tumbuhan yang dapat digunakan untuk mengobati penyakit diare yaitu dengan mengkonsumsi buah babal (anak buah nangka) dan salak. Cara mengolah obat tradisonal dari tumbuhan babal dan salak :

a. Caranya cukup mudah yaitu kalau babal bisa langsung dimakan dan juga dimakan dengan garam sesuai selera masing masing

b. Untuk salak sendiri cukup langsung dimakan 
4. Batuk

Menurut informan tumbuhan yang dapat digunakan untuk mengobati penyakit batuk pada anak-anak yaitu bisa menggunakan air rebusan bunga belimbing wuluh. Proses pembuatannya cukup mudah yaitu:

a. Cuci bersih bunga belimbing wuluh yang akan digunakan

b. Rebus bunga belimbing wuluh dengan air secukupnya

c. Kemudian tambahkan gula sedikit saja

d. Rebus hingga air berubah warna menjadi merah

e. Lalu jika sudah mendidih matikan dan dinginkan terlebih dahulu

f. Saring air rebusan agar bunga belimbing wuluh tidak tercampur

g. Berikan kepada sang anak 1 sdt saja

5. Sariawan

Untuk mengobati sariawan narasumber biasanya menggunakan madu atau bisa juga menggunakan jeruk nipis. Cara penggunaannya cukup mudah yaitu dengan mengoleskan sari jeruk nipis kebagian yang terluka (sariawan) menggunakan cottonbud.

6. Rematik

Menurut informan tumbuhan yang dapat digunakan untuk mengobati penyakit rematik yaitu bisa menggunakan tanaman lengkuas yang menggunakan bagian rimpangnya. Proses pembuatannya cukup mudah yaitu:

a. Ambil 2 rimpang lengkuas kemudian diparut

b. Setelah itu peras parutan lengkuas hingga keluar airnya saja

c. Kemudian campurkan air perasan tersebut dengan telur ayam kampong, kocok hingga merata

d. Minum campuran air lengkuas dengan telur. Diminum 1 kali sehari

7. Asam Urat

Menurut informan tumbuhan yang dapat digunakan untuk mengobati penyakit asam urat yaitu bisa menggunakan campuran tanaman lengkuas, serai, jahe, jeruk nipis, kunyit, kencur yang menggunakan bagian rimpangnya. Proses pembuatannya cukup mudah yaitu:

a. Ambil bahan bahan tersebut sesuai selera

b. Tumbuk lengkuas, jahe, kunyit, dan kencur

c. Lalu rebus semua bahan menjadi satu

d. Tunggu kurang lebih 30 menit (hingga air benar benar menyerap)

e. Saring air rebusan tadi setelah dingin

f. Minum jamu tersebut 1 hari 2 kali 


\section{KESIMPULAN}

Masyarakat di desa Pecoro kecamatan Rambipuji tercatat menggunakan 17 spesies tumbuhan dari 12 famili. Masyarakat desa Pecoro mendapatkan pengetahuan tentang tanaman obat ini secara turun temurun dari nenek moyang atau orang tua terdahulu. Bagian tumbuhan yang sering digunakan yaitu bagian rimpang, selain rimpang bagian yang digunakan adalah kulit, buah, bunga, batang dan daun.

Adapun cara pengolahannya dilakukan dengan berbagai macam cara, di antaranya yaitu direbus, ditumbuk, diparut, atau dikonsumsi langsung. Dalam penggunaan tanaman obat tersebut, terdapat 7 macam khasiat di antaranya pengobatan setelah melahirkan, diabetes, diare, batuk, sariawan, rematik, dan asam urat.

\section{DAFTAR PUSTAKA}

\section{Buku}

Dewi , Fannia Kusuma; Novian Wildan Rosyidi; Sisi Cahyati. (2017). Manfaat Kunyit (Curcuma longa)dalam Farmasi. Surakarta: Universitas Sebelas Maret.

Heinrich, M., Barnes, J., Gibbons, S., \& Williamson, E. M. (2009). Farmakognosi dan Fitoterapi. Jakarta: EGC.

Mardawani. (2020). Praktis Penelitian Kualitatif Teori Dasar Dan Analisis Data Dalam Perspektif Kualitatif. Yogyakarta: Deepublish.

\section{Jurnal/Prosiding/Disertasi/Tesis/Skripsi}

D.E. Dermawaty. (2015). Potential Extract Curcuma (Curcuma Xanthorrizal, Roxb) As Antibacterials. Jurnal Majority, 4(1).

Ersam, T. (2004). Keunggulan biodiversitashutan tropika Indonesia dalam merekayasa model molekul alami. Prosiding Seminar Nasional Kimia VI. ITS Surabaya.

Idolo M, R Motti \& S Mazzoleni .(2009). Ethnobotanical and phytomedicinal knowledge in a long-history protected area, of the Abruzzo, Lazio, and Molise National Park (Italian appenines). Journal of Ethnopharmacology, (127):379-395.

Kurniawan, Erwin, and Nurul Jadid. 2015. "Nilai Guna Spesies Tanaman Sebagai Obat Tradisional Oleh Masyarakat Tengger Di Desa Probolinggo - Jawa Timur." Jurnal Sains dan Seni ITS 4(1): 1-4. www.dephut.go.id/informasi/bromo.

Suryana, Y., \& Iskandar, J. (2014). Studi pengetahuan lokal tanaman obat pada agroekosistem pekarangan dan dinamika perubahannya di Desa Cibunar Kecamatan Rancakalong Kabupaten Sumedang-Jawa Barat. Bionatura, 15(3), 217948.

Syifa, N., Sihdianto, A. D., Herjuno, A., \& Salash, A. F. (2011). Studi Etnofarmasi Etnis Using Banyuwangi Indonesia. Farmasains: Jurnal Farmasi dan Ilmu Kesehatan, 1(2).

Syukrillah, Ghalib, Mutiara Ayudia Astuti, and Dayar Arbain Piter, Piter. 2021. "KAJIAN ETNOFARMASI DAN FITOKIMIA TUMBUHAN OBAT KAMPUNG." Tumbuhan obat 
indonesia 14(1): 14-28.

Yulia Ningsih, Indah. (2016). Studi Etnofarmasi Penggunaan Tumbuhan Obat Oleh Suku Tengger Di Kabupaten Lumajang Dan Malang, Jawa Timur. Pharmacy, Vol.13 No. 01.

\section{Lain-lain}

Bodeker. G. (2000). Indigenous Medical Knowledge : The Law and Politics of Protection : Oxford Intelektual Property Research Center Seminar in St. Peter's College, 25th January 2000. Oxford.

Depkes RI. (2007). Kebijakan Obat Tradisional Nasional. Jakarta: Departemen Kesehatan Republik Inodonesia. 